Revue Interventions économiques

Papers in Political Economy

$56 \mid 2016$

Développement et inclusion. Le grand chantier des inégalités, de la pauvreté

\title{
Sur les inégalités, la pauvreté, les économies « à marché émergent » et le développement : dix questions à James Kenneth Galbraith
}

On Inequality, Poverty, Emerging Market Economies and Development: Ten

Questions to James Kenneth Galbraith

Chalmers LaRose

\section{OpenEdition}

\section{Journals}

\section{Electronic version}

URL: http://journals.openedition.org/interventionseconomiques/2948

DOI: 10.4000/interventionseconomiques.2948

ISBN: $1710-7377$

ISSN: $1710-7377$

Publisher

Association d'Économie Politique

Electronic reference

Chalmers LaRose, « Sur les inégalités, la pauvreté, les économies « à marché émergent » et le développement : dix questions à James Kenneth Galbraith », Revue Interventions économiques [Online], 56 | 2016, Online since 01 November 2016, connection on 15 September 2020. URL : http:// journals.openedition.org/interventionseconomiques/2948

This text was automatically generated on 15 September 2020

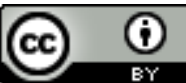

Les contenus de la revue Interventions économiques sont mis à disposition selon les termes de la Licence Creative Commons Attribution 4.0 International. 


\title{
Sur les inégalités, la pauvreté, les économies « à marché émergent » et le développement : dix questions à James Kenneth Galbraith
}

\author{
On Inequality, Poverty, Emerging Market Economies and Development: Ten \\ Questions to James Kenneth Galbraith
}

Chalmers LaRose
" The main challenge facing our societies is to find employment for those who want it, and to create institutions that provide employment in sectors and activities that are actually socially constructive. "

1 James K. Galbraith est titulaire de la Chaire Lloyd M. Bentsen Jr. in Government/ Business Relations et professeur à la Lyndon B. Johnson School of Public Affairs de l'Université du Texas à Austin. Il est diplômé de Harvard et Yale (Ph. D. en économie, 1981). James Galbraith tient également une chronique dans The Texas Observer et écrit régulièrement dans The Nation, The American Prospect, Mother Jones et The Progressive. On retrouvera également ses chroniques sur le site du CEIM à l'adresse suivante :

2 http://www.ieim.uqam.ca/spip.php?page=mot-ceim\&id_mot=318

3 Son plus récent ouvrage Inequality: What everyone needs to know (Oxford University Press, 2016) aborde les problèmes liés à l'accroissement des inégalités dans le monde et dresse un portrait lucide et saisissant des questions urgentes de notre temps.

4 De passage à Montréal le 3 avril 2016, Professeur Galbraith nous a livré ses réflexions sur les enjeux relatifs au développement économique et social des pays émergents. Il a abordé des sujets brûlants, tels que l'accroissement/diminution des inégalités, la spirale de la pauvreté et la place des politiques publiques et du marché dans l'établissement du bien-être collectif. 
5 1. In your recent book about inequality entitled « Inequality: what everyone needs to know ", you address a whole set of issues, theoretical, conceptual and empirical. What should we (students, researchers, policymakers, decision makers, and citizens) need to know now about inequality in the 21st century?

6 J. G. That is a question about which I have written an entire book. My best suggestion is that those interested should read it.

7 2. In recent years, as a result of both sustained economic growth as well as aggressive redistributive policies, poverty has been declining in the world. Yet, at the same time, inequality has been rising in many parts of the world. How can you explain this paradox?

8 J. G.First of all, I am not entirely sure that is an accurate characterization. Let's take the two pieces of it. If we look at the world as a whole up until the year 2000, significant decline in deep poverty occurred primarily in one country, which is China. And so this is a very particular phenomenon that is specific to the Chinese experience. After 2000, there were further gains, substantial ones, especially in Latin America and parts of Africa. And the main reasons for that are, first of all, favorable economic conditions, in particular high commodity export prices, but also a reorientation of policy in those regions away from the highly anti-egalitarian Washington consensus that dominated the previous generation. So given that, in Brazil for example, one had a consolidated policy for fifteen years of social housing, health care, education, and so on. It is not surprising, and it's very heartening, that deep poverty in Brazil was reduced very substantially between 2000 and 2015. As that phenomenon happened there and elsewhere in Latin America, inequality also declined.

What had happened in China is another story. Inequality certainly rose in China through much of the period of rapid growth. And that was primarily because the cities are much richer than the countryside. So as the cities developed, initially Shanghai, Beijing and the cities of Guandong province, especially Guangzhou, you had a growing gap between the rich and the poor. This was compounded, in the period of economic reforms, by increasing incomes in certain sectors, including finance, utilities and transportation, which enjoyed monopoly power as the economy became more market-oriented.

10 My evidence is that after about 2002, the inter-regional gap tended to stabilize and even decline, mainly because urbanization spread out well beyond the leading cities and provinces, and became dominant in other provinces, such as Zhejiang, Jiangsu, Fujian and elsewhere. And then after 2008, finance and some of the other monopoly sectors also lost some of their lustre. So in our most recent data, we see some leveling and even decline in inequality in China, which others are also finding as survey data come in.

11 3. Ideas about how to fight inequality vary from one expert to another. And, in some instances, some argue that there might a « tolerance threshold " in which inequality would be acceptable. What is your opinion on this controversy?

12 J. G. Well, to a certain degree, inequality is inevitable. No society escapes it entirely. The question remains, to what degree one regulates it and keeps it under reasonable control. I think the experience of the world I have investigated suggests that societies that do a better job of keeping inequality under control have many advantages, including advantages on the social side, and advantages in terms of productivity and higher levels of employment. So it's a good idea to have effective regulatory and tax mechanisms to control inequality. And in order to do that, there are basically two sides of distribution that you have to worry about. At the lower end, higher minimum wage and social insurance are the most important measures; at the higher end, 
it's the control of those sectors that are the most effectively predatory, particularly finance. If you can keep the financial sector under some degree of control, then you have a chance of stablising the society, precisely because you are controlling the most destabilising force.

4. Can the objectives of eliminating poverty be achievable without reducing the level of inequality in a given society?

J. G. Not on a sustainable basis. We do occasionally observe that you get a business boom that is associated with rising levels of inequality and also lots of jobs. The period of the late 1990s in the United States had that character. But it fell apart in the 2000s, because everything that is built on credit is essentially and inevitably transitory.

5. For some, during the last centuries, economic growth has been unprecedented and, since the Industrial Revolution of the 19th century, the world has become more egalitarian. Hence, capitalism might not be the problem but the solution? How do you respond to that line of reasoning?

16 J. G. Well, I would argue that the classical capitalism collapsed during the 1920s, and what was built up in the 20th century in every advanced society was a mixed economy in which there was a very large and stable public sector, and that is essential to counterbalance the destabilising dynamic and inegalitarian tendencies of the capitalist private sector. That model of a mixed economy was severely weakened during and after the 1980s, and with predictable results. The world became more unequal and unstable.

17 If you look forward into the present century, we have a new set of problems that developed out of the success of the 20th century capitalism, especially climate change, which we have to deal with by an entirely different set of mechanisms, if it's going to be dealt with at all. So we can't go back to these earlier models as examples of what we need to do now, because we are facing problems we have not faced before. But we should, nevertheless, learn from the experience we actually had, and not from some imaginary construct called "free market capitalism» that never actually existed.

18 6. You partly answered this question earlier, but I would like you to elaborate further on this issue. In your opinion, what is the best way to fight inequality in today's modern industrialised societies? Some suggest that state intervention should tax the richest segments of societies, whereas others propose to help the poor. Still, others are of the view that the solution relies on the growth of revenues of middle-class families in relation to the productivity growth rate.

J. G. All three of these things are different sides of the same policy. Every advanced society taxes the wealthy more than it taxes the poor. And should. The definition of a civilised society is one in which your payment into the common wealth is in proportion, at least, to your capacity to pay. So every advanced and civilized society has standards which hold up the base for the population as a whole, which includes wage standards, public education, social insurance, health insurance, unemployment insurance, nutrition assistance, insurance of bank deposits, etc.

So there is a set of institutions that serve everybody. And that is the feature of advanced societies without which they would not have the success or the population they are presently able to sustain.

21 When you put those two things together, the result is a middle class. The features of a middle class that are crucial are a sense of the population that you have a reasonable degree of economic security, and a reasonable prospect for maintaining your living standards over a substantial period into the future. 
Multiocade Trends?" odd years, it's the "demographic sweet spot" of labor oversupply that has kept wages low and allowed competitive pricing to drive down inflation. As population growth slowing and populations ageing in Western countries, the same is true in China, exacerbated by China's infamous one child policy. As a result, we are entering a phase where the global labour supply is shrinking due to both Western

Revue Interventions économiques, 56 | 2016 
and Chinese demographics. The implication is that the trends that we have experienced over the past 30 years could start going into reverse: higher wages, more expensive goods, higher inflation, a savings shortfall, higher interest rates and stagnant asset prices. Is demographics the real engine of inequality?

J. G.I would be extremely skeptical of that analysis. In the Chinese case, to begin with, we are not talking about the overall gross increase of the population but the flow of labour from the villages to the cities. That is the demographic force that is at issue here. It could have been happening with a rapidly growing, a slowly growing or even a declining population. That's industrialisation/urbanization process rather than a demographic acceleration or deceleration perse.

As China becomes a predominantly urban society, which is close to happening - that transition is now pretty far advanced - does that mean there will be a shortage of workers in the manufacturing sector? No, that's preposterous. The manufacturing sector simply isn't that large, and in every Chinese City the proportion of people outside manufacturing as compared to those inside is enormous. Most people are in service activities as they are everywhere in the world, shops and various sectors of non-manufacturing activities. So the notion that factories are going to run out of workers simply because there are not enough of teenage girls to staff the cubicles of Foxconn (the subcontractor for Apple) is a big stretch of a simple idea to me. in the United States? Well, the United States has been facing this problem for many years and to the extent that it has required more workers it is relying on immigrants for that. And that will continue. Another factor that runs counter to the demographic trend is the technology factor. New technologies have been radically cutting back on the demand for labour generally. who want it, and to create institutions that provide employment in sectors and activities that are actually socially constructive. There are still massive gaps in education, in the caring professions (child care, elder care) and in dealing with our environmental questions. And if we dealt with those by carrying out the great project of institutional construction that is required to make that happen, then we will have met the challenge.

On that positive note, I thank you very much for your time and generosity in sharing your thoughts with Interventions Économiques. It was a very important moment talking to you. I wish you all the best in the future. 